\title{
ASSOCIATIONS BETWEEN EXCLUSIVE BREASTFEEDING, DIARRHEA, AND RISK OF STUNTING AMONG CHILDREN WITH LOW BIRTHWEIGHT
}

\author{
Frienty Sherlla Mareta Lubis \\ Masters Program in Nutrition, Sebelas Maret University
}

\begin{abstract}
Background: Stunting is a serious public health problem among children in Indonesia, because it can determine their quality in later life. There are some known risk factors for stunting, among others is low birthweight. The purpose of this study was to determine the associations between exclusive breastfeeding, diarrhea, and stunting in children aged 12-24 months with low birthweight.

Subjects and Method: This was an analytic cross-sectional study. It was carried out in 2 subdistricts in Surakarta, Central Java. A sample of 98 children aged 12-24 months with low birthweight were selected for this study using purposive sampling. The dependent variable was stunting. The independent variables were exclusive breastfeeding and diarrhea. Stunting was measured by anthropometry. The other data were collected by questionnaire and analyzed using multiple logistic regression.

Results: Exclusive breastfeeding ( $\mathrm{OR}=0.67 ; 95 \% \mathrm{CI}=0.30$ to $1.47 ; \mathrm{p}=0.318$ ) and no history of diarrhea $(\mathrm{OR}=0.49 ; 95 \% \mathrm{CI}=0.23$ to $1.07 ; \mathrm{p}=0.074)$ were associated with reduced risk of stunting.

Conclusion: Exclusive breastfeeding and and no history of diarrhea is associated with reduced risk of stunting.
\end{abstract}

Keywords: stunting, exclusive breastfeeding, diarrhea

Correspondence: Frienty Sherlla Mareta Lubis. Masters Program in Nutrition, Sebelas Maret University. Email: Ellalubis74lagi@gmail.com 